\title{
Quality Characteristics of Stirred Yoghurt Added with Fermented Red Pepper
}

\author{
Mi-Sang Yu ${ }^{1, \#}$, Jeong-Mee Kim²,\#, Chi-Ho Lee ${ }^{2,3}$, Yoon-Jeong Son ${ }^{1}$, and Soo-Ki Kim ${ }^{1,2, *}$ \\ ${ }^{1}$ Department of Animal Science and Technology, Konkuk University, Seoul 143-701, Korea \\ ${ }^{2}$ Institute of Animal Resource Center, Konkuk University, Seoul 143-701, Korea \\ ${ }^{3}$ Department of Food Science \& Biotechnology of Animal Resources, Konkuk University, Seoul 143-701, Korea
}

\begin{abstract}
Pungency of hot pepper has limited its usage even though it shows various health beneficial effects. This study was conducted to develop the novel yoghurt containing hot pepper with diminishing pungency and aimed to examine the quality characteristics of yoghurt prepared with fermented red pepper. Hot pepper was first fermented with Bacillus licheniformis SK1230 to reduce the pungency of capsaicin. We then examined the quality, sensory characteristics, and antioxidant activity of yoghurt containing the fermented red pepper. The titratable acidity of this yoghurt increased whereas the viscosity decreased with increasing amounts of added red pepper. The total polyphenol content increased in proportion to the amount of added red pepper. The antioxidant activity significantly increased with the addition of red pepper $(p<0.05)$. Color evaluation showed that the $L$ value decreased whereas the $a$ and $b$ values increased significantly with the amount of red pepper added $(p<0.05)$. In the sensory evaluation, yoghurt prepared with higher amounts of fermented red pepper received lower scores. However, yoghurt containing fermented red pepper at a concentration of $0.05 \%$ received higher scores for taste, flavor, and overall acceptability than yoghurt prepared with non-fermented pepper. Therefore, it can be concluded that the application of red pepper fermented by Bacillus licheniformis SK1230 gives beneficial feature to the preparation of yoghurt.
\end{abstract}

Keywords: stirred yoghurt, quality characteristics, fermented red pepper, DPPH, antioxidant activity, B. licheniformis

\section{Introduction}

Capsaicin is the principal pungent component of chili pepper. It is associated with enhanced lypolysis and the sparing of stored glycogen owing to an increase in circulating catecholamines (Lee et al., 2010). Currently, there is an increasing interest in natural treatments to control dyslipidemia and to reduce the risk of cardiovascular disease. Adipose tissue has an important role in maintaining the energy balance and homeostasis (Lee et al., 2011). Recently, research has been conducted on natural antiobesity substances that prevent fat storage and accelerate fat disintegration, which could have applications in weight control and obesity management (Lee et al., 2009). Capsaicin has numerous biological roles, such as the enhancement of thermogenesis and fat consumption as well

\footnotetext{
\#These authors contributed equally to this work.

*Corresponding author: Soo-Ki Kim, Department of Animal Science and Technology, Konkuk University, Seoul 143-701, Korea. Tel: +82-2-450-3728, Fax: +82-458-3728, E-mail: sookikim@konkuk.ac.kr
}

as analgesic, anti-inflammatory, and antioxidant activities (Hayman and Kam, 2008; Surh, 2002). However, despite its medicinal benefits, the strong pungency of red pepper restricts its widespread use. Therefore, this study aimed to reduce the pungency of hot pepper and produce healthy food made with red pepper with good flavor.

Yoghurt is a widely consumed functional food because of its high digestibility, bioavailability, and proteolytic activities (Shabboo and Ahmad, 2011). It strengthens the immune system, improves lactose ingestion and blood glucose management (Yadav et al., 2007), helps relieve constipation and diarrhea, and has potential health benefits in colon cancer, inflammatory bowel disease, and allergies (Adolfsson et al., 2004). Research on bioactive functional yoghurt include studies on the supplementation of dietary fiber (Damian, 2013; Min et al., 2012), cultured ginseng as an anticancer agent (Lee et al., 2003), micronutrients (Sazawal et al., 2013), black garlic extract as an anti-inflammatory agent (Shin et al., 2010), omega-3 polyunsaturated fatty acids (McCowen et al., 2010), vitamin D (Shab-Bidar et al., 2011), isoflavone (Cavallini et al., 2009), and green tea powder (Jung et al., 2005). 
The aim of this research was to manufacture functionally fortified yoghurt containing fermented red pepper with increased antioxidant activity. We measured the quality characteristics of stirred yoghurt added with red pepper that was fermented with Bacillus licheniformis SK1230 to reduce pungency.

\section{Materials and Methods}

\section{Preparation of red pepper powder}

Red pepper (Capsicum annuum cv. Chungyang), which is cultivated in Cheong-Yang, Chungchung Nam-do province, during September, was purchased fresh from a local market, washed with clean water, and ground (without adding water) using a mixer (Dasung Health Mix, DA $5000)$. The ground pepper was sterilized in an autoclave at $120^{\circ} \mathrm{C}$ for $20 \mathrm{~min}$. The red pepper powder was then freeze-dried and stored in a refrigerator.

\section{Preparation of fermented red pepper}

Bacillus licheniformis SK1230 was grown in LB broth or solid medium (Difco ${ }^{\mathrm{TM}}$, BD, Franklin Lakes, NJ, USA). The overnight culture was inoculated at $1 \%$ in bacillus minimal medium (BMM). The BMM was composed of $\mathrm{Na}_{2} \mathrm{HPO}_{4} \cdot 7 \mathrm{H}_{2} \mathrm{O}, 33.5 \mathrm{mM} ; \mathrm{KH}_{2} \mathrm{PO}_{4}, 22 \mathrm{mM}$; $\mathrm{NaCl}$, $8.6 \mathrm{mM} ; \mathrm{NH}_{4} \mathrm{Cl}, 18.7 \mathrm{mM} ; \mathrm{MgSO}_{4}, 1 \mathrm{mM} ; \mathrm{CaCl}_{2}, 0.1 \mathrm{mM}$; glucose, $10 \mathrm{mM}$. Red pepper powder $(3 \%)$ was added to the BMM, and the mixture was sterilized and fermented at $37^{\circ} \mathrm{C}$ for $48 \mathrm{~h}$. The fermented red pepper was pasteurized at $90^{\circ} \mathrm{C}$ for $10 \mathrm{~min}$ and used for the preparation of yoghurt.

\section{Preparation of stirred yoghurt}

Fermented or non-fermented red peppers was added to milk at concentrations of $0-0.1 \%$ and homogenized (Homogenizer T 25, Janke and Kunkel type, Ika, Staufen, Germany). Streptococcus thermophilus, Lactobacillus delbrueckii ssp. bulgaricus, Lactobacillus acidophilus, and Bifidobacterium animalis ssp. lactis (Lyofast YAB 450 AB, Sacco srl., Codaragok, Italy) were inoculated as detailed in Fig. 1 and fermented for $5 \mathrm{~h}$. The yoghurt was stored at $4^{\circ} \mathrm{C}$ for $24 \mathrm{~h}$.

\section{Analysis of yoghurt component, $\mathrm{pH}$ and titratable acid}

The yoghurt component was analysed by Milkoscan (Milkosan Minor 78110, Foss Co., Denmark). The pH of the homogenized yoghurt was determined using a digital pH meter (ISTEC 735P, Korea). Titratable acid (TTA) was

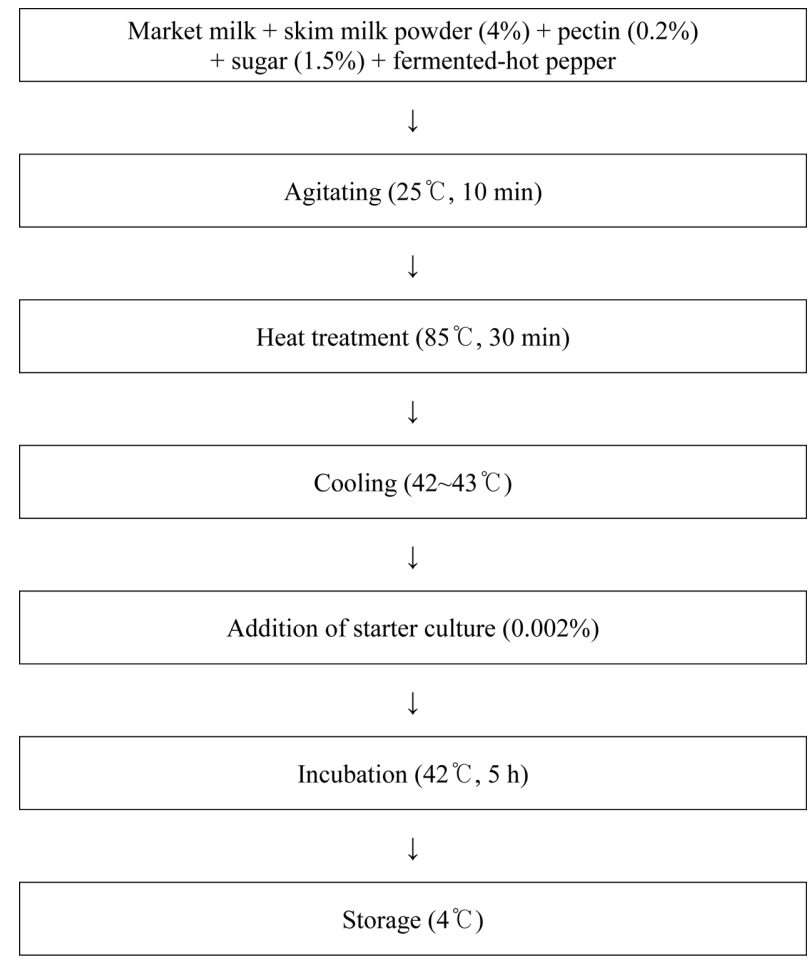

Fig. 1. Procedure for the manufacture of stirred yoghurt with added fermented red pepper.

determined by titration with $0.1 \mathrm{~N} \mathrm{NaOH}$. Yoghurt sample (3 g) was transferred into an Erlenmeyer flask containing $27 \mathrm{~mL}$ of $\mathrm{dH}_{2} \mathrm{O}$. Three to five drops of $0.1 \%$ phenolphthalein as $\mathrm{pH}$ indicator were added. The yoghurt mixture was then titrated with $0.1 \mathrm{~N} \mathrm{NaOH}$ with continuous stirring until a stable pink color was achieved. The amount of acid produced during fermentation was calculated as follows:

TTA $(\%$ Lactic acid $)=$ Dilution factor $\times V_{\mathrm{NaOH}} \times 0.1 \mathrm{~N}$ $\mathrm{NaOH}$ Factor $\times 0.009 /$ weight of sample $(\mathrm{g}) \times 100$

Where $V_{\mathrm{NaOH}}$ is the volume $(\mathrm{mL})$ of $0.1 \mathrm{~N} \mathrm{NaOH}$ required to neutralize the acid; a dilution factor of 10 was used.

\section{Enumeration of lactic acid bacteria in yoghurt}

The agar plate was incubated at $37^{\circ} \mathrm{C}$ for $48 \mathrm{~h}$. Total microorganism counts were determined on MRS agar and expressed as CFU (colony-forming units)/mL.

\section{Measurement of viscosity}

The viscosity of the yoghurt, which was stored at $4^{\circ} \mathrm{C}$, was measured using a Brookfield-Viscometer (Model LV DV 1+, Version 3.0, Strongton, M. CoA, USA) with spindle No. 63 at $100 \mathrm{rpm}$ for 5 to $8 \mathrm{~min}$. 


\section{Measurement of color}

The color of the yoghurt was measured using the Hunter Lab color meter (Minolta chromameter CR-210) and expressed as $L, a$, and $b$ values. $L$ value represents lightness, $a$ value represents redness, and $b$ value represents yellowness. The $L, a$, and $b$ values on a standard color plate were $97.83,-0.45$, and 2.00 , respectively.

\section{Total polyphenol content assay}

Water extract from yoghurt containing red pepper (1.0 $\mathrm{mL})$ was mixed with methanol $[9.0 \mathrm{~mL}, 95 \%(\mathrm{v} / \mathrm{v})]$ and 9 $\mathrm{mL}$ of $\mathrm{dH}_{2} \mathrm{O}$. Folin-Ciocalteu reagent $(1 \mathrm{~mL}, 1 \mathrm{~N})$ was added to each supernatant, and after being thoroughly mixed, the solutions were allowed to stand for $3 \mathrm{~min}$ at room temperature. $\mathrm{Na}_{2} \mathrm{CO}_{3}(300 \mu \mathrm{L}, 1 \mathrm{~N})$ was then added, and absorbance at $725 \mathrm{~nm}$ (UV-1601, Shimadzu, Japan) was read after incubation for a further $90 \mathrm{~min}$ at room temperature (Wei, 2011). Known concentrations of gallic acid (Sigma-Aldrich, Germany; 5-60 $\mu \mathrm{g} / \mathrm{mL}$ in ethanol) were treated in the same manner as the water extracts of yoghurt, and the regression of gallic acid standards was used to convert unknown samples to total phenolic content [ $\mu \mathrm{g}$ gallic acid equivalent ( $\mu \mathrm{g} \mathrm{GAE}) / \mathrm{mL}]$.

Determination of antioxidant activity using the 1,1diphenyl-2-picrylhydrazyl radical (DPPH) inhibition assay

DPPH inhibition was determined as described by Shetty et al. (1995). Briefly, $1 \mathrm{~mL}$ of $0.15 \mathrm{mM}$ DPPH (SigmaAldrich, Germany) was mixed with $4 \mathrm{~mL}$ of yoghurt extract or $4 \mathrm{~mL}$ of water, which served as a control. The mixture was shaken thoroughly and allowed to stand at room temperature for $30 \mathrm{~min}$. The constant absorbance readings at $517 \mathrm{~nm}$ were recorded using a spectrophotometer (UV-1601, Shimadzu, Japan) at $5 \mathrm{~min}$, and inhibition of DPPH oxidation (\%) was calculated as follows (Apostolidis et al., 2007):

$\%$ Inhibition $=\left(A_{\text {control }}-A_{\text {extract }}\right) / A_{\text {control }} \times 100$

Where $A$ is absorbance at $517 \mathrm{~nm}$.

\section{Sensory analysis}

Sensory analyses were carried out by 10 trained assessors between 20 and 50 years of age. The samples were coded with three digit numbers and randomly served at 7 to $10^{\circ} \mathrm{C}$ in plastic cups $(10 \mathrm{~mL})$. The assessors completed a test assessment form to compare the five sensory attributes (taste, flavor, appearance, hot taste, and overall ac- ceptability) by using a five-point hedonic scale (1, extremely poor; 2, poor; 3, fair; 4, good; 5, excellent). Pungency was scored as follows: 5 , strong; 3 , medium; 1 , mild.

\section{Statistical analysis}

Three separate experiments with triplicate assays were performed. Data were expressed as means + SEM (standard error of the mean). Statistical analysis was performed using one-way analysis of variance (ANOVA; SPSS 20) followed by Duncan's post hoc test for mean comparison. Statistical significance was established as $p<0.05$.

\section{Results and Discussion}

\section{pH, TTA, growth of probiotics, and viscosity}

The control yoghurt without red pepper contained total solids $14.3 \%$, moisture $82.84 \%$, protein $3.53 \%$, fat $3.92 \%$, lactose $6.38 \%$, and ash $0.2 \%$. The $\mathrm{pH}$ and TTA of yoghurt prepared with 0 to $0.1 \%$ fermented or non-fermented red pepper are shown in Fig. 2A and B, respectively. The $\mathrm{pH}$ was decreased to around 4.3 after the fermentation of yoghurt mixture. Yoghurt with 0.05-0.1\% fermented red pepper showed a slightly higher $\mathrm{pH}$ than yoghurt with the same concentration of non-fermented pepper (Fig. 2A). Lee et al. (2010) reported that the $\mathrm{pH}$ of pepper fermented with Bacillus subtilis P3-3 increased with incubation time.

The constantly higher TTA in yoghurt added with fermented red pepper compared to that in non-fermented yoghurt (Fig. 2B) could be attributed to higher acid production due to the addition of fermented red pepper during the preparation of yoghurt. Yoghurt added with red pepper showed TTA contents in the range of 0.91 to $1.0 \%$, similar to the TTA content of domestic commercial yoghurt $(0.92-1.40 \%)$. TTA is generally high depending on the decrease of $\mathrm{pH}$. However, the addition of fermented red pepper showed a different tendency with some unknown reason.

The lactic acid bacteria (LAB) count of yoghurt with 0 to $0.1 \%$ red pepper is shown in Fig. $2 \mathrm{C}$. The LAB count of yoghurt prepared with $0.025 \%$ fermented red pepper increased significantly compared with that of yoghurt with non-fermented red pepper. However, with the addition of fermented red pepper at concentrations of 0.075 to $0.1 \%$, the LAB count of yoghurt decreased significantly, whereas that of non-fermented pepper-containing yoghurt was not changed. These results showed that the addition of $0.05 \%$ or higher concentrations of red pepper was not good for the LAB growth. 

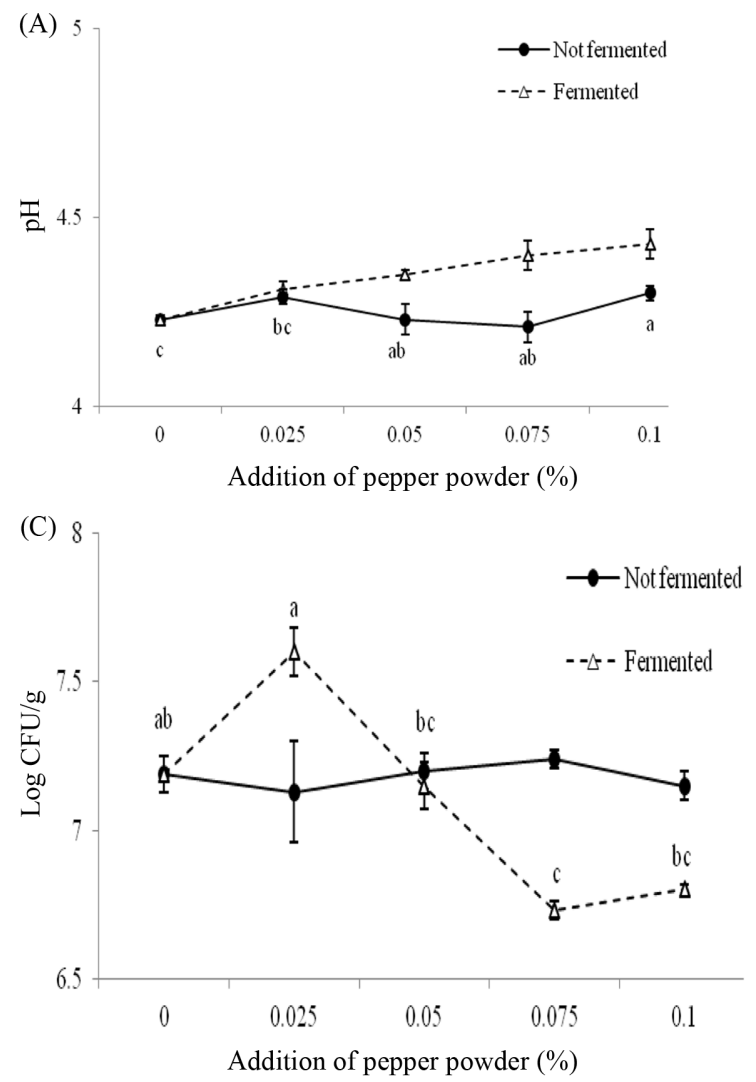
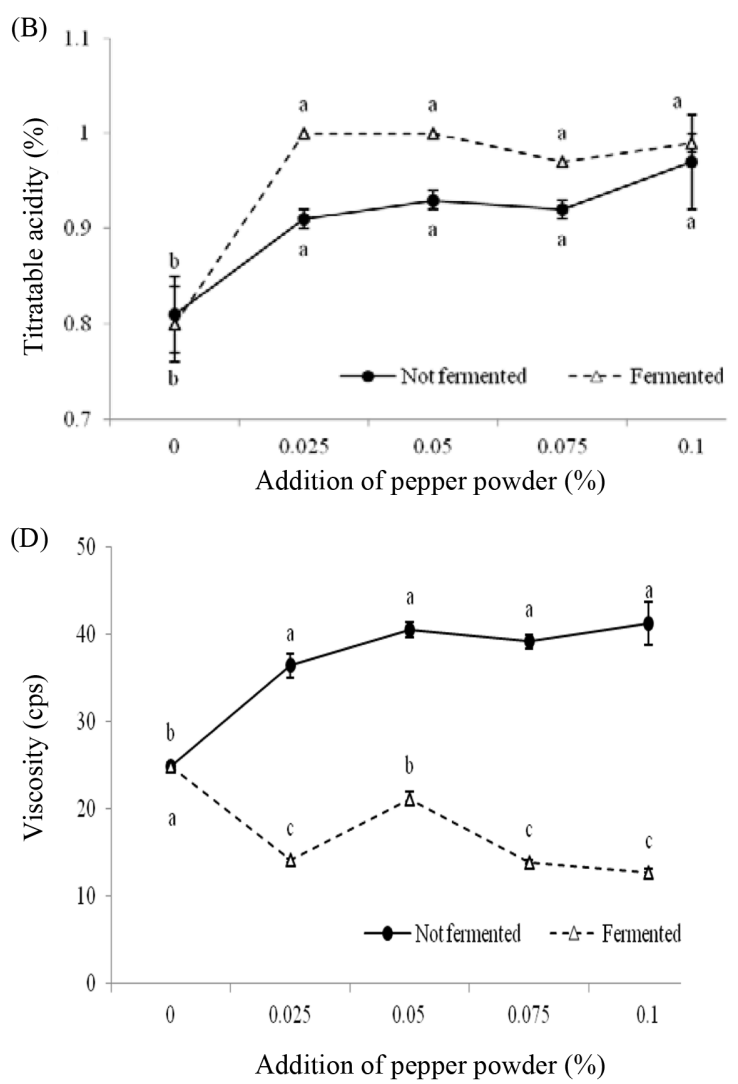

Fig. 2. Changes in $\mathbf{p H}$, titratable acidity, viable cell count, and viscosity of yogurt with fermented red pepper. (A) $\mathrm{pH}$; (B) Titratable acidity; (C) Viable cell count; (D) Viscosity. Means with different superscript letters are significantly different $(p<0.05)$.

The viscosity of plain yoghurt with red pepper was determined with a viscometer as shown in Fig. 2D. The viscosity of yoghurt with added fermented red pepper decreased significantly compared with that of yoghurt with non-fermented red pepper, whereas the viscosity of nonfermented red pepper-containing yoghurt was significantly higher than that of plain yoghurt without red pepper. The decrease in viscosity could be attributed to the fermentation activity of LAB. There was no correlation between viscosity and $\mathrm{pH}$ in either fermented or non-fermented red pepper-containing yoghurts. Chung et al. (2006) reported that the viscosity of yoghurt with added enzymatic oyster hydrolysates increased proportionally with the amount of LAB. Shin et al. (2010) reported that the viscosity of yoghurt decreased because of increased acid production.

\section{Color changes}

The color changes in yoghurt added with 0 to $0.1 \%$ fermented red pepper, measured using Hunter $L, a$, and $b$ values, are shown in Table 1. The addition of fermented pepper led to a decrease in brightness, with significant differences observed upon varying the amounts of red pep- per compared with no addition. The $L$ value of fermented pepper-containing yoghurt ranged from 84.4 to 88.38 , indicating a relatively bright color. On the other hand, the $L$ value of non-fermented pepper-containing yoghurt gradually decreased from 88.38 to 85.58 with the addition of up to $0.1 \%$ of pepper. These data showed that increasing the amount of red pepper led to a decrease in brightness. The $a$ value (redness) significantly decreased after the addition of red pepper, whereas the $b$ value (yellowness) increased. The $a$ value (redness) decreased from -3.12 in plain yoghurt to -4.02 with the addition of up to $0.1 \%$ fermented red pepper, whereas the $b$ value (yellowness) increased significantly. Increasing the amount of red pepper in yoghurt gave it a more yellowish color. Yoghurt prepared with Maca (Lepidium meyenii) hot water extract also showed a decrease in $L$ value, whereas the Hunter $a$ and $b$ values increased (Chung et al., 2010).

\section{Total polyphenol content}

Phenolic compounds are widely found in various plants. They are generally water-soluble and have excellent antioxidative effects. The total polyphenol contents (TPC) from water and ethanol extracts of red pepper in yoghurt 
Table 1. Color changes in yoghurt with added fermented red pepper

\begin{tabular}{|c|c|c|c|c|c|c|c|}
\hline & \multirow{2}{*}{ Pepper powder } & \multicolumn{5}{|c|}{ Addition of pepper powder $(\%)$} & \multirow{2}{*}{$p$ value } \\
\hline & & 0 & 0.025 & 0.05 & 0.075 & 0.1 & \\
\hline \multirow{3}{*}{$\begin{array}{c}\mathrm{L} \\
\text { (Lightness) }\end{array}$} & Non- fermented & $88.38 \pm 1.13^{\mathrm{a}}$ & $84.87 \pm 1.14^{\mathrm{c}}$ & ${ }^{\mathrm{A}} 87.88 \pm 0.64^{\mathrm{a}}$ & ${ }^{\mathrm{A}} 86.77 \pm 0.92^{\mathrm{ab}}$ & $85.58 \pm 0.94^{\mathrm{bc}}$ & 0.0058 \\
\hline & Fermented & $88.38 \pm 1.13^{\mathrm{a}}$ & $84.83 \pm 0.54^{\mathrm{c}}$ & ${ }^{\mathrm{B}} 85.80 \pm 0.86^{\mathrm{bc}}$ & ${ }^{\mathrm{B}} 84.40 \pm 0.60^{\mathrm{c}}$ & $86.27 \pm 0.33^{b}$ & 0.0005 \\
\hline & $p$-value & 1.0000 & 0.9554 & 0.0283 & 0.0202 & 0.2993 & - \\
\hline \multirow{3}{*}{$\begin{array}{c}\mathrm{a} \\
\text { (Redness) }\end{array}$} & Non-fermented & $-3.12 \pm 0.23^{b}$ & $-2.59 \pm 0.42^{\mathrm{a}}$ & $-3.48 \pm 0.18^{\mathrm{bc}}$ & B $-3.57 \pm 0.25^{\text {bc }}$ & $-3.79 \pm 0.23^{c}$ & 0.0026 \\
\hline & Fermented & $-3.12 \pm 0.23^{b}$ & $-2.46 \pm 0.16^{\mathrm{a}}$ & $-3.16 \pm 0.26^{\mathrm{b}}$ & ${ }^{\mathrm{A}}-3.06 \pm 0.19^{\mathrm{b}}$ & $-4.02 \pm 0.06^{\mathrm{c}}$ & $<0.0001$ \\
\hline & $p$-value & 1.0000 & 0.6503 & 0.1574 & 0.0456 & 0.1658 & - \\
\hline \multirow{3}{*}{$\begin{array}{c}\mathrm{b} \\
\text { (Yellowness) }\end{array}$} & Non- fermented & $7.64 \pm 1.47^{\mathrm{ab}}$ & $6.22 \pm 0.91^{\mathrm{b}}$ & $8.26 \pm 0.75^{\mathrm{a}}$ & $8.63 \pm 0.16^{\mathrm{a}}$ & ${ }^{\mathrm{B}} 8.86 \pm 0.81^{\mathrm{a}}$ & 0.0675 \\
\hline & Fermented & $7.64 \pm 1.47^{\mathrm{b}}$ & $5.23 \pm 0.31^{\mathrm{c}}$ & $7.19 \pm 0.81^{b}$ & $7.39 \pm 0.49^{b}$ & ${ }^{\mathrm{A}} 10.28 \pm 0.33^{\mathrm{a}}$ & 0.0003 \\
\hline & $p$-value & 1.0000 & 0.1509 & 0.1676 & 0.1526 & 0.0476 & - \\
\hline
\end{tabular}

Data are means \pm SD.

Means with different superscripts are significantly different $(p<0.05)$.

${ }^{\mathrm{A}-\mathrm{B}}$ Within a column, different letters indicate significant differences $(p<0.05)$.

${ }^{\mathrm{a}-\mathrm{c}}$ Within a row, different letters indicate significant differences $(p<0.05)$.

(A)

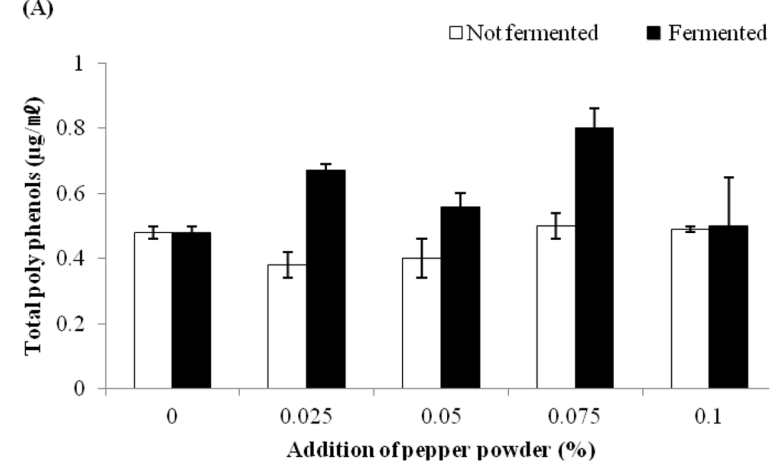

(B)

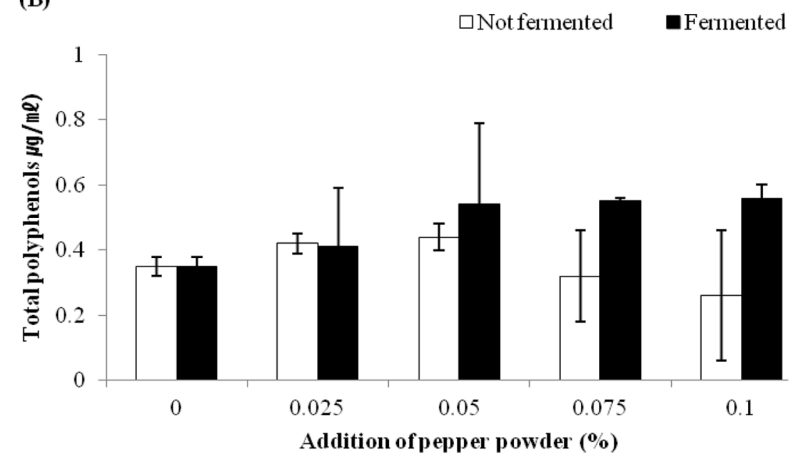

Fig. 3. Total polyphenol contents of yoghurt with fermented red pepper. (A) Water extract; (B) Methanol extract.

are shown in Fig. 3. For both water and methanol extracts, yoghurt with added fermented red pepper showed significantly higher TPC than yoghurt with non-fermented red pepper, and TPC increased proportionally with the amount of fermented red pepper added. We suggest that the elevated TPC in yoghurt is associated with an increase in the antioxidant activities of fermented red pepper. TPC in the methanol extracts from fermented red pepper yoghurt was also higher than non-fermented one. Jeon
(A)

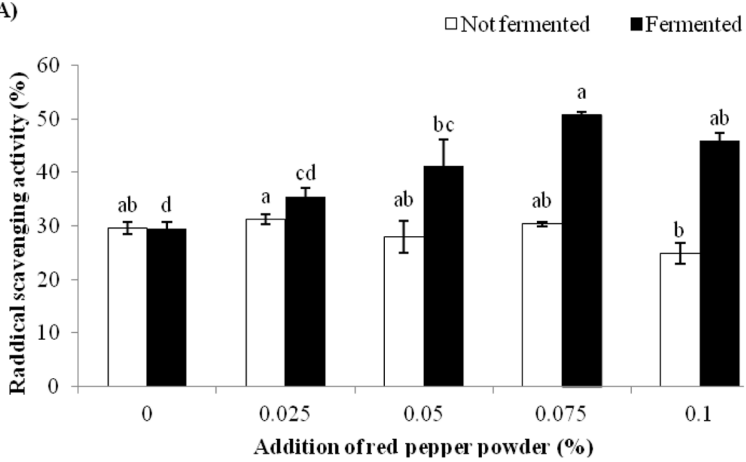

(B)

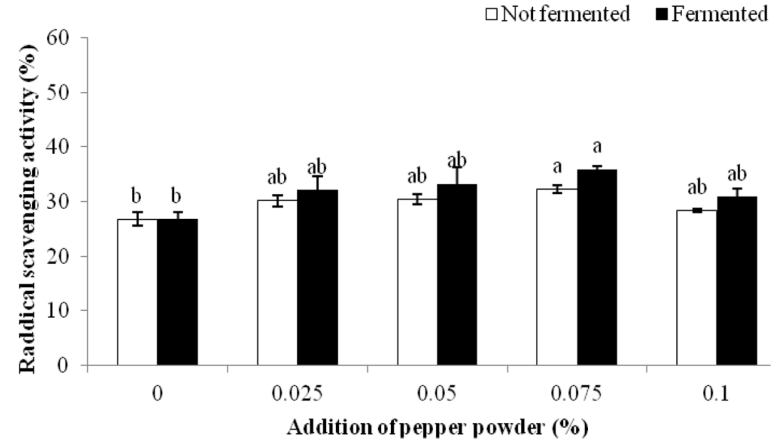

Fig. 4. DPPH radical-scavenging activity of fermented red pepper-containing yoghurt. (A) Water extract; (B) Methanol extract.

(2011) reported that yoghurt showed increased TPC when Dioscorea batatas fermented by Monascus sp. and Lactobacillus sp. was added to it. The higher TPC in red pepper-containing yoghurt may be due to the herb's indigenous phytochemical compounds.

\section{Antioxidant activity}

The antioxidant activity of water extract from fermen- 
ted red pepper-containing yoghurt was increased significantly $(p<0.05)$ compared to that of non-fermented red pepper-containing yoghurt (Fig. 4A). Non-fermented red pepper-containing yoghurt showed little change in antioxidant activity. Similar to the result for TPC, the antioxidant activity of the water extract was higher than that of the methanol extract, as shown in Fig. 4B. The addition of red pepper water extract resulted in an increase in antioxidant activity (Fig. 4A), similar to the pattern observed for TPC (Fig. 3A). This finding indicates that the polyphenols of red pepper mainly contribute to the antioxidant properties of yoghurt. The higher antioxidant activities in red pepper-containing yoghurt were likely due to the herb's antioxidant properties (Thompson et al., 2007). The reduction in antioxidant activities during refrigerated storage of yoghurt is attributed to increasing degradation of phenolic compounds with antioxidant activities (Yildiz and Eyduran, 2009) or increasing milk protein-polyphenol interaction (Yuksel et al., 2010).

\section{Sensory evaluation}

The sensory properties of the yoghurt were evaluated by 10 trained panels of ages 20 to 50 years, and the results are summarized in Table 2. The yoghurt was prepared with red pepper at concentrations of 0 to $0.1 \%$. The taste scores for yoghurt with fermented red pepper ranged from 3.45 to 2.43 , which were higher than those for yoghurt with non-fermented peppers (2.91 to 2.26). The taste, flavor, color, and overall acceptability decreased in propor- tion to the added amount of red pepper. The flavor score of non-fermented red pepper-containing yoghurt ranged from 3.39 to 2.52 , whereas that of fermented red peppercontaining yoghurt ranged from 3.64 to 2.52. The color value of non-fermented red pepper-containing yoghurt ranged from 3.57 to 2.78 , which was comparable to that of fermented red pepper-containing yoghurt, 3.91 to 2.71 . The hot taste increased with the amount of red pepper added. Fermented red pepper-containing yoghurt had a lower score than non-fermented red pepper-containing yoghurt, indicating a reduced pungency of red pepper after fermentation. In the addition of $0.025 \%$ fermented red pepper, its hot taste decreased significantly compared with non-fermented red pepper-containing yoghurt $(p<0.05)$. The fermented red pepper contained reduced capsaicinoids (data not shown). The overall acceptability decreased with increasing amounts of added red pepper. High scores were received by non-fermented red pepper-containing yoghurt with $0.025 \%$ red pepper and fermented red pepper-containing yoghurt with $0.05 \%$ red pepper. Therefore, the addition of fermented red pepper in yoghurt improved the functional properties such as antioxidant activity as well as the sensory characteristics of yoghurt. These results indicate that the addition of fermented red pepper at a concentration of $0.05 \%$ would be good for the production of pungency-reduced and functionally enriched yoghurt fortified with antioxidant, anti-obesity, and antiinflammatory components.

In conclusion, the addition of fermented pepper to yo-

Table 2. Sensory characteristics of yoghurt with fermented red pepper

\begin{tabular}{|c|c|c|c|c|c|c|c|}
\hline \multirow{2}{*}{ Attributes } & \multirow{2}{*}{ Pepper powder } & \multicolumn{5}{|c|}{ Addition of pepper powder (\%) } & \multirow{2}{*}{$p$ value } \\
\hline & & 0 & 0.025 & 0.05 & 0.075 & 0.1 & \\
\hline \multirow{3}{*}{ Taste } & Non-fermented & $2.91 \pm 1.24$ & $2.70 \pm 1.06$ & $2.91 \pm 1.31$ & $2.26 \pm 1.21$ & $2.26 \pm 1.14$ & 0.1448 \\
\hline & Fermented & $3.45 \pm 1.13^{\mathrm{a}}$ & $3.14 \pm 0.85^{\mathrm{ab}}$ & $3.24 \pm 1.14^{\mathrm{ab}}$ & $2.71 \pm 1.06^{\mathrm{bc}}$ & $2.43 \pm 0.75^{\mathrm{c}}$ & 0.0174 \\
\hline & $p$-value & 0.2296 & 0.1338 & 0.3866 & 0.1953 & 0.5701 & - \\
\hline \multirow{3}{*}{ Flavor } & Non- fermented & $3.39 \pm 1.08^{\mathrm{a}}$ & $2.87 \pm 0.97^{\mathrm{abc}}$ & $3.26 \pm 1.21^{\mathrm{ab}}$ & $2.61 \pm 0.94^{\mathrm{bc}}$ & $2.52 \pm 1.24^{\mathrm{c}}$ & 0.0267 \\
\hline & Fermented & $3.64 \pm 1.12^{\mathrm{a}}$ & $3.29 \pm 1.06^{\mathrm{ab}}$ & $3.14 \pm 1.11^{\mathrm{abc}}$ & $2.67 \pm 1.00^{\mathrm{bc}}$ & $2.52 \pm 0.75^{\mathrm{c}}$ & 0.0114 \\
\hline & $p$-value & 0.5440 & 0.1797 & 0.7388 & 0.8412 & 0.9947 & - \\
\hline \multirow{3}{*}{ Color } & Non- fermented & $3.57 \pm 1.20^{\mathrm{a}}$ & $3.22 \pm 1.00^{\mathrm{ab}}$ & $3.30 \pm 0.97^{\mathrm{ab}}$ & $2.78 \pm 0.90^{\mathrm{b}}$ & $2.83 \pm 0.98^{b}$ & 0.0504 \\
\hline & Fermented & $3.91 \pm 1.30^{\mathrm{a}}$ & $3.52 \pm 1.03^{\mathrm{ab}}$ & $3.10 \pm 0.62^{b c}$ & $2.86 \pm 0.85^{\mathrm{c}}$ & $2.71 \pm 0.85^{\mathrm{c}}$ & 0.0022 \\
\hline & $p$-value & 0.4520 & 0.3223 & 0.4065 & 0.7802 & 0.6894 & - \\
\hline \multirow{3}{*}{ Hot taste } & Non-fermented & $1.22 \pm 0.52^{\mathrm{d}}$ & $\mathrm{A}_{2.39 \pm 1.08^{\mathrm{c}}}$ & $2.96 \pm 1.02^{b}$ & $3.22 \pm 1.04^{\mathrm{b}}$ & $3.83 \pm 1.03^{\mathrm{a}}$ & $<0.0001$ \\
\hline & Fermented & $1.27 \pm 0.65^{\mathrm{c}}$ & ${ }^{\mathrm{B}} 1.71 \pm 0.78^{\mathrm{c}}$ & $2.38 \pm 1.07^{\mathrm{b}}$ & $3.10 \pm 1.00^{\mathrm{a}}$ & $3.38 \pm 1.12^{\mathrm{a}}$ & $<0.0001$ \\
\hline & $p$-value & 0.7898 & 0.0227 & 0.0753 & 0.6936 & 0.1761 & - \\
\hline \multirow{3}{*}{$\begin{array}{c}\text { Overall } \\
\text { acceptability }\end{array}$} & Non- fermented & $3.13 \pm 1.14^{\mathrm{a}}$ & $2.91 \pm 1.08^{\mathrm{a}}$ & $2.83 \pm 1.15^{\mathrm{a}}$ & $2.13 \pm 1.06^{\mathrm{b}}$ & $2.09 \pm 1.00^{\mathrm{b}}$ & 0.0023 \\
\hline & Fermented & $3.55 \pm 1.21^{\mathrm{a}}$ & $3.05 \pm 1.07^{\mathrm{ab}}$ & $3.33 \pm 0.80^{\mathrm{a}}$ & $2.57 \pm 0.98^{b}$ & $2.43 \pm 1.03^{b}$ & 0.0054 \\
\hline & $p$-value & 0.3379 & 0.6812 & 0.1001 & 0.1597 & 0.2695 & - \\
\hline
\end{tabular}

Data are means \pm SD.

Means with different superscripts are significantly different $(p<0.05)$.

${ }^{\mathrm{A}-\mathrm{B}}$ Within a column, different letters indicate significant differences $(p<0.05)$.

${ }^{\mathrm{a}-\mathrm{c}}$ Within a row, different letters indicate significant differences $(p<0.05)$. 
ghurt resulted in increased titratable acidity and decreased viscosity. The polyphenol content and antioxidant activity of yoghurt significantly increased with the amount of fermented pepper added. In sensory evaluation, yoghurt containing fermented pepper received higher scores for taste, flavor, and overall acceptability.

\section{Acknowledgements}

This research was supported by the Ministry for Food, Agriculture, Forestry, and Fisheries, Republic of Korea.

\section{References}

1. Adolfsson, O., Meydani, S. N., and Russel, R. R. (2004) Yogurt and gut function. Am. J. Clin. Nutr. 80, 245-256.

2. Apostolidis, E., Kwon, Y. I., and Shetty, K. (2007) Inhibitory potential of herb, fruit, and fungal-enriched cheese against key enzymes linked to type 2 diabetes and hypertension. Innov. Food Sci. Emerg. Technol. 8, 46-54.

3. Cavallini, D. C., Aballa, D. S., Vendramini, R. C., Bedani, R., Bomdespacho, L. Q., and Rossi, E. A. (2009) Effects of isoflavone-supplemented soy yoghurt on lipid parameters and atherosclerosis development in hypercholesterolemic rabbits; a randomized double-blind study. Lipid Health Dis. 8, 40-49.

4. Chung, H. J., Chu, Y. R., Park, H., Jeng, I. S., and Kang, Y. S. (2010) Influence of the addition of MACA hot water extract on the quality and antioxidant activity of yoghurt. Korean $J$. Food Culture. 25, 334-341.

5. Chung, I. K. and Kim, H, S., Kang, K.T., Choi, J. D., Heu, M. S., and Kim, J. S. (2006) Preparation and characterization of enzyme oyster hydrolysates-added yoghurt. Korean J. Food Sci. Nutr. 35, 926-934.

6. Damian, C. (2013) Influence of dietary fiber addition on some properties of yoghurt. Ovidius university Annals of Chemistry 24, 17-20.

7. Hayman, M. and Kam, P. C. (2008) Capsaicin: A review of its pharmacology and clinical applications. Curr. Anaesth. Crit. Care 19, 338-343

8. Jeon, C. P., Lee, J. B., Choi, C. S., and Kwon, G. S. (2011) Physiological effect of yogurt with powder two stage fermented Discorea batatas Dence by Monascus sp. and Lactobacillus sp. Kor. J. Microbiol. 47, 151-157.

9. Jung, D. A. and Park, S. I. (2005) Preparation of drinkable yoghurt added with green tea powder. Korean J. Food Nutr. 18, 349-356.

10. Lee, I. S. and Paek, K. Y. (2003) Preparation and quality characteristics of yoghurt added with cultured ginseng. Korean J. Food Sci. Technol. 35, 235-241.

11. Lee, M. S., Kim, C. T., Kim, I. H., and Kim, Y. (2009) Inhibitory effects of green tea catechin on the lipid accumulation in 3T3-L1 adipocytes. Phytother. Res. 23, 1088-1091.

12. Lee, M. S., Kim, C. T., Kim, I. H., and Kim, Y. (2011) Effects of capsaicin on lipid catabolism in 3T3-L1 adipocytes. Phytother. Res. 25, 935-939.

13. Lee, S. M., Lee, H. S., Lee, J., Yu, K. W., and Suh, H. J. (2010)
Non-pungent capsicum fermentation by B. subtilis P3-3 and its swimming endurance capacity in mice. Enzyme Microb. Technol. 47, 200-205.

14. McCowen, K. C., Ling, P. R., Decker, E., Djorjevic, D., Roberts, R. F., and Bistrian, B. R. (2010) A simple method of supplementation of omega-3 polyunsaturated fatty acids: use of fortified yoghurt in healthy volunteers. Nutr. Clin. Pract. 25, 641-645.

15. Min, Y. W., Park, S., Jang, Y. S., Rhee, P. L., and Chang, D. K. (2012) Effect of composite yoghurt enriched acacia fiber and B. lactis. World J. Gastroenterol. 18, 4563-3569.

16. Sazawal, S. Habib, A. A., Dhingra, U., Dutta, A., Dhingra, P., Sarkar, A., and Black, R. E. (2013) Impact of micronutrient fortified of yoghurt on micronutrient status markers and growth-a randomized double blind controlled trial among school children in Bangladesh. BMC Public Health 13, 514525.

17. Shaboo, A. and Ahmad, S. B. (2011) Changes in yoghurt fermentation characteristics, and antioxidant potential and in vitro inhibition of angiotensin-1 converting enzyme upon the inclusion of peppermint, dill and basil. LWT-Food Sci. Technol. 44, 1458-1464.

18. Shab-Bidar, S., Neyestans, T. R., Djazayeng A., and Haidari, H. (2011) Regular consumption of vitamin D-fortified yoghurt dring (Doogh) improved endothelial biomarkers in subjects with type 2 diabetes: a randomized double-blind clinical trial. BMC Med. 9, 125-132.

19. Shetty, K., Curtis, O. F., Levin, R. E., Witkowsky, R., and Ang, W. (1995) Prevention of vitrification associated with in vitro shoot culture of oregano. (Origanum vulgare) by Pseudomonas spp. J. Plant Physiol. 147, 447-451.

20. Shin, J. H., Kim, G. M., Kang, M. J., Yang, S. M., and Sung, N. J. (2010) Preparation and quality characteristics of yogurt with black garlic extracts. Korean J. Food Cookery Sci. 26, 307-313.

21. Surh, Y. J. (2002) Anti-tumor promoting potential of selected spice ingredients with antioxidative and anti-inflammatory activities; a short review. Food Chem. Toxicol. 202, 1091-1097.

22. Thompson, J. L., Lopetcharat, K., and Drake, M. A. (2007) Preferences for commercial strawberry drinkable yoghurts among African American, Caucasian, and Hispanic consumers in the United States. J. Dairy Sci. 90, 4974-4987.

23. Yadav, H., Jain, S., and Sina, S. H. (2007) Antidiabetic effect of probiotic data containing Lactobacillus acidophilus and Lactobacillus casei in high fructose fed rats. Nutrition 23, 62-68.

24. Yildiz, O. and Eyduran, S. P. (2009) Functional components of berry fruits and their usage in food technologies. Afri. $J$. Agric. Res. 4, 422-426.

25. Yuksel, Z., Avci, E., and Erden, Y. K. (2010) Characterization of binding interactions between green tea flavonoids and milk proteins. Food Chem. 121, 450-456.

26. Wei, X., Luo, M. Xu, L., and Liu, H. (2011) Production of fibrinolytic enzyme from Bacillus amyloliquefaciens by fermentation of chickpeas, with the evaluation of the anticoagulant and antioxidant properties of chickpeas. J. Agric. Food Chem. 59, 3957-3963.

(Received 2013.10.24/Revised 2014.3.13/Accepted 2014.4.16) 